\title{
Strategic Fight Against Terrorism: A Narrative of its Implication in the Sahel Region
}

\author{
Stephen Osaherumwen Idahosa $^{1 *}$, Denis Andreevich Degterev ${ }^{1}$, Rasheed Olasunkanmi Abidoye $^{1}$ \\ ${ }^{\text {I} P e o p l e s ' ~ F r i e n d s h i p ~ U n i v e r s i t y ~ o f ~ R u s s i a ~(R U D N ~ U n i v e r s i t y), ~ M i k l u k h o-M a k l a y a ~ H o u s e ~ 10 / 2, ~ M o s c o w, ~ 117198, ~ R u s s i a ~}$ \\ *Corresponding author E-mail: idahosa.s.o@mail.ru
}

\begin{abstract}
This paper explores the major impediments to peace and widespread interest in Sahel violence and stability. It examines the expansion of violent extremism across the Sahel and the direct consequence of unrest across North Africa. It assesses worrisome development in the region's security landscape as these violent extremist organizations grow and develop sophisticated networks. It discovers that these emerging threats can be illustrated by the unique challenges facing Libya, Mali, Nigeria, and other countries in the region. Hence the strategies and assistance of Major Powers in ensuring the security and stability of the Sahel region, as it goes well beyond terrorism. Methodologically, it employs the use of descriptive analysis relying solely on secondary information for data generation and articulation. The study therefore suggests among others that, rather than attempt to stifle regional conflicts through military intervention, Major Powers should encourage regional initiatives. Many regional conflicts are so deeply rooted, however powers involve should recognize that, for there to be success in ending the fighting and instability, it should avoid policies that often clash with realities and needs on the ground, without which no outside party, from within or outside the region will succeed in putting an end to the threat to peace and security challenge.
\end{abstract}

Keywords: Instability Sahel, International cooperation; Intervention; Major Powers; NATO; Regional conflict.

\section{Introduction}

The Sahel is a sparsely populated area with porous borders, little central government control of rural areas, and vast distances between population centers in the south and deserts in the north where the terrorists operate [1].

The trends of Regional conflicts have greatly increased since the end of the Cold War, the analysis of the contemporary situation may contend that it promises to continue. An effective strategy in the Sahel, will requires that Sahel states counter radical ideologies that fuel recruitment and provide alternatives to terrorist and criminal activity to ensure vulnerable populations do not view extremist activity as either spiritually or economically beneficial [1]. The ostensible reason for military build-up of foreign troops (United States, France, Germany, the Netherlands, Sweden, Canada and now, Russia) over the few years in Sahel, specifically Niger has been counter-terrorism. Stifling of regional conflicts for many years now, has been as a result of superpower confrontations accruing from the escalating of the threat of tensions. Since the end of cold war, age old disputes across the globe have erupted, resulting to increase in regional conflict. The 2002 Pan-Sahel Initiative (PSI) grew out of U.S. strategic shift originating from the September 11, 2001 attacks on the United States. The National Security Strategy of the United States expressing the global war on terror, birthed in 2002, was in 2003 implemented [3]. On the other hand, the French military intervention in Mali, in January 2013, with the aim of chasing the Islamist insurgents, extremists, out of Mali, was the beginning of western militarization of the Sahel region. The expansion of military intervention and redeployment away from a limited success "France's Operation Serval" to a further 3,000 troops by France in mid-2014 through Mali, Niger and Chad called Operation Barkhane, was as a result of the regrouping of the jihadists that were initially scattered and chased by the French troops.

Amidst security initiatives the region lacks migrant and refugee protection mechanisms and practices, save the United Nations High Commission on Refugees (UNHCR) enforcement of Refugee Status Determination schemes [4]. The status being illegal immigrants in states that serves as transit for vulnerable and economic migrants fleeing their states as a result of either conflict, environmental devastation or institutional failures (maybe all combine). At a certain point they, in this situation lose protection under the 1951 Convention on Refugees, tantamount to limiting the ability of humanitarian organizations to provide assistance [5]. To this end, counter-terrorism-policing is the problem and not the height of refugees and Terrorism.

Therefore, for the purpose of understanding, the definition of regional conflict is of essence. There are series of definition on "Regional conflict" and there exist the complexity in its precise definition. The term is used in different ways. However, to the aim of this analysis, the term will mean an armed up-heaval, either Transborder or internal, that affects a controlled area but has major or diminutive direct impact on the security of the rest of the world [6] But for the purpose of this study, the definition is; applicable to; a dispute between a sovereign government and an armed group within its borders; or a conflict that involves both sovereign states and external nonstate parties, as in Libya.

Where gaps in governance in hostile territories are often seen to serve as terrorist havens, which are used as prerequisites to quickly shaping the agendas of foreign interventions in the region and beyond. This bases for intervention in the Sahel by major powers, is what Anneliese refers to as "the new class of interventionism" 
[5]. This paper will examine how counterterrorism and security approach has been used in the Sahel and how it has failed to sustainably strengthen Sahelian states.

\section{Research Methodology}

The paper uses historical and qualitative research method. It is, firstly, a process of systematic examination of an account and descriptive in nature as it seeks to understand the consequences and the adverse effect of the strategies of major powers in the stability of the Sahel region, by implication instability across $\mathrm{Sa}-$ hel states in comparative perspective. And why the West is internationalizing its militarization in the Sahel region as it relates to the fight against the spread of terrorism in the region.

\section{Theoretical Perspective}

Choi and Powers [7] submits that "although military interventions may increase transnational terrorism by creating target-rich environments for these attacks, by prompting individuals to utilize this tactic for the defense of their homeland, or for grievance-based reasons, the ability of individuals to utilize terrorism during interventions may ultimately depend on the intensity of the intervention in question" (pp. 28-29). On the intervention in Libya, Azikiwe [8] noted that the United States operates not on the basis of human rights considerations or the need to facilitate democracy, but upon its own economic and political interests in the entire region.

A study conducted at New York University's Centre on Law and Security further found that American interventionism has increased the prevalence of terrorism in the Sahel [9]. Data from the Memorial Institute for the Prevention of Terrorism (MIPT) database, a public index of terrorist incidents established after the Oklahoma City bombing of 1995 appeared to support the assertion. The index found that after the launch of Operation Iraqi Freedom, there was a 607 percent rise in the average annual occurrence of jihadist attacks worldwide and a 237 percent rise in the average fatality rate from those attacks. The report, endorsed by John D. Negroponte, Director of National Intelligence, goes on to describe the Iraq War as a "“cause célèbre' for jihadists."

Military intervention often arises as an option to conflict within a region, the later however cannot be resolved just by the act of such intervention. Actually, intervention of such frequently heightens the already precarious state. The justifications for military involvement in such conflict has always been based on a number of interest, ranging on security and humanitarian issues. While, some proponents are of the view that, arguing on global instability as a threat to security is common and fallacious. Policy based on the later on the premise of instability always being a threat to security, compels major powers to utilize vast resources in pursuit of an unattainable objective - peace and stability [6]. "Peace is not the normal state of affairs. Equilibrium in the international system is not a natural or automatically realized phenomenon," concedes former assistant secretary of state Elliott Abrams. While, Richard Reeve, 2014, few years now, the impact of the French intervention in northern Mali has been felt in most of the surrounding countries [10]. Jeremy H. Keenan a Professorial Research Associate at the School of Oriental and African Studies (SOAS) at the University of London, argued that, the US's launch of its global war on terror into the Sahel provoked Tuareg rebels to take up arms and so gain further military and financial support from Washington. Adding that, the overthrow of the Qadhafi regime in Libya in 2011 further destabilized much of the Sahel which triggered a further Tuareg rebellion in northern Mali. While, Zyck S.A. \& Muggah R. [11] supporting the claim asserted that, the intervention in Libya triggered the instability in the region.

\section{Brief Background Analysis}

The spread of jihadism, political instability and bad governance in Africa's Sahel in combinations, are argued to have contributed to a deteriorating security situation and conflict in the region. Under the pretense of militarization been the key to the increasing and intensifying complex problems in the Sahel, major powers like, US, France, Germany, etc. have since 2013 increase their military presence in the region. However, the presence of major powers military trend in the region in support of the UN's Multidimensional Integrated Stabilization Mission in Mali (Minusma) has also attracted other lesser powers (Sweden and Holland). The peacekeeping force amounting to 13,000 seems ineffectual in ensuring peace and stability - jihadists are still carrying out their deadly act. In addition to the activities of major countries and support for France efforts against "antiterrorism", Canada has promised strategic airlift for the latter's effort. The critical state of insecurity in the region may also have a contributing factor from the power struggle of major powers, example, is China role as a major economic player in most of the countries in the region. The struggle for influence and resources by these actors can also be a factor. According to Richard Reeve's [10] argument, China is also increasingly active in the Sahel. Its parastatals are the dominant actors in the oil industries of Sudan/South Sudan, Chad/Cameroon and Niger. They also mine uranium in Niger, and China is the primary buyer of iron ore from Mauritania's vast desert complexes. While Russia interest on the region security situation is coming to manifestation by the feeling of its resent presence in the Sahel [12] The arrival of a high-level Russian delegation in Bamako through 11-12 October 2017 cannot have been comforting for Western powers.

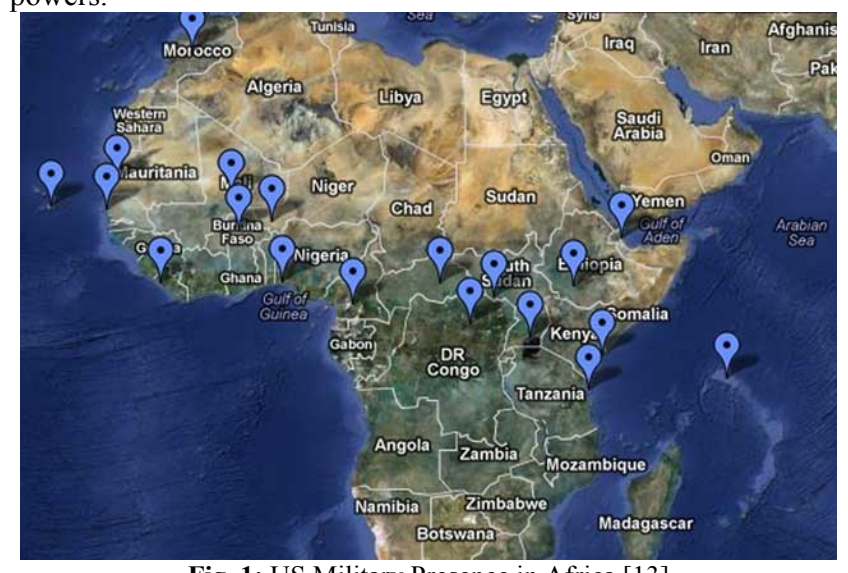

Fig. 1: US Military Presence in Africa [13]

Agadez the contemporary military base for major powers, in late September 2016, the United States interest is being expressed in different dimension, which includes $3 \mathrm{~km}$ runway and associated infrastructure for a drone in construction at Agadez (Niger) by the former as declared by Pentagon spokeswoman, Michelle Baldanza. This will be used to conduct reconnaissance operations over Niger and Chad, as well as Libya and Nigeria, and further afield. One of the support through the use of drone (MQ-9 Reaper drones) to the French operation (taged "Operation Barkhane") is being owned by the United States. German's Ambassador to Niger, Bernd von Muenchow-Pohl, made an announcement few days after Pentagon's, Bernd von Muenchow-Pohl address was on Germany building a military base in Niger (close to the Malian border) to support the UN mission in neighboring Mali. 


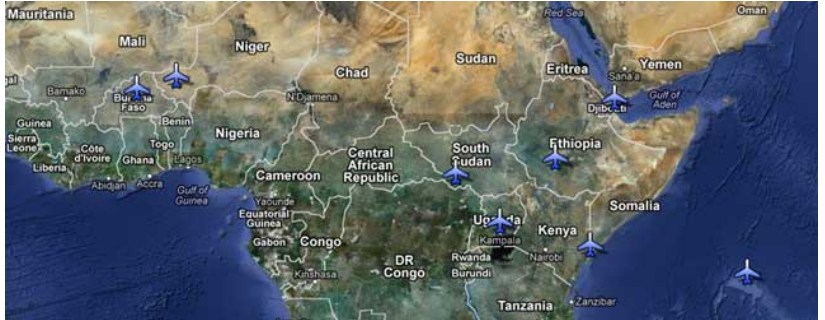

Fig. 2: Drone Bases in Africa [13]

In the words of the German Ambassador, "Niger is a central partner, a key country, for us in the fight against terrorism and illegal migration from West Africa." Angela Merkel, the German Chancellor after her arrival from her visit to Mali and Niger, she hosted Chad's President Idriss Déby. Two days after Angela Merkel, the German Chancellor met with Déby, October 14, 2016, she hosted Nigeria's President Muhammadu Buhari. The key on Merkel's agenda were the fight against terrorism and curbing migration, same as her meeting with Mali, Niger and Chad. Apart from migration flow, security and counter terrorism officials and researchers, including analysts in US, Europe and china are beginning to see Niger as the key "crossroads" position in this part of Africa, as it stands between Libya and Nigeria and between the increasingly troubled Mali to the West and the equally vulnerable Chad to the east. However, more seriously, injudicious military intervention in regions that consequently increases instability and conflict, as in the Sahel region, can adversely create threats to national security of the interventionists where none previously existed, stoking the fires of "anti-major powernism". These ultimately result to jeopardizing the lives of their troops, and consequently undermining the stability of the affected region.

France's military intervention, after many years, has not been able to end "terrorism" across the region. According to General de, the Sahel's jihadists probably could not take and hold a town; nor are they capable of "industrialised terrorism". But to try and suggest that the French military has had great success against terrorism in the region, or that the region is now stable, is misleading. The major powers military intervention in the Sahel has not been a total success. Neither the security nor the political stability of the region have dramatically improved. Because of this, the militarization of the region is now being internationalized. In most cases regional conflicts cannot be helped and may well be exacerbated by the intervention of outside parties. Major powers intervention can be especially counterproductive, since it often intensifies smaller, less powerful countries' (the very nation's most likely to be involved in regional conflicts and instability).

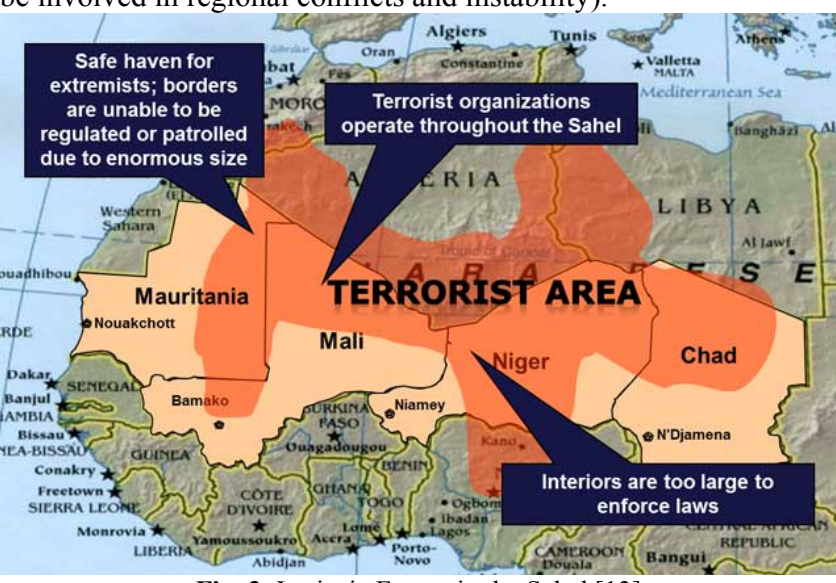

Fig. 3: Intrinsic Forces in the Sahel [13]

\section{Strategies of US Counter-Terrorism Opera- tions in the Sahel: TSCTP}

The Munich Olympics terrorist attack gave birth to counterterrorism programme that began in 1972 under the auspices of the
United States Department. The evolvement of the anti-terrorism activities over the years has among others include military and development initiatives. Development agenda of the United States with the aim to boost security, stability, and prosperity has however taken center stage through security imbedded in AFRICOM's mission [5]. Whose direct agenda is the response to the menace of terrorism in Sahel. It however seems complex, as demonstrated by the exceptional ability of Trans-Sahara Counterterrorism Partnership (TSCTP), to position interagency resources of the '3Ds' diplomacy, defence and development in support of a regional security approach [14].

The vehicle of U.S. counterterrorism policy in West Africa and the Maghreb is the Trans-Sahara Counterterrorism Partnership (TSCTP). The TSCTP finds its roots in the less ambitious PanSahel Security Initiative (PSI), which was initiated and developed in 2002 by US European Command to enhance the counterterrorism capacity of the militaries of Chad, Mali, Mauritania, and Niger. It was envisioned as a direct response to the risks emanating from the training camps of terrorists and their safe havens, as a result of the vacuum created by weak states and their ungoverned territories. The PSI train and equip swift response force to counter terrorism in the four Sahel States (Mali, Chad, Niger and Mauritania) [15]

The chronology and development over time saw PSI evolved to Trans-Sahara Counterterrorism Initiative (TSCTI) in 2005 and to Trans-Sahara Counterterrorism Partnership (TSCTP) in 2008 with the United States Africa Command (AFRICOM) [16]. The TSCTP grew to a multi-year, with multi-agency effort to support diplomacy, development, and military activities in combating the spread of Islamic extremism in nine countries: Chad, Mali, Mauritania, Niger, Morocco, Algeria, Tunis, Senegal and Nigeria (Burkina Faso was added in 2009). Led by the Department of State's Africa Bureau, key participating agencies include the Department of State (DOS), the U.S. Agency for International Development (USAID), and the Department of Defense (DoD) [3].

In November 2009, the Assistant Secretary of State for African Affairs Johnnie Carson in a testimony before the Senate Committee of Foreign Relations Subcommittee on Africa, stated that, as the lead for the TSCTP, the partnership has two primary purposes. First, the TSCTP is to identify and mobilize resources throughout the interagency to support sustained efforts to address violent extremism in the region. To achieve long-term results, the emphasis is to be placed upon key capacity deficits that can be addressed over a period of years through the resources and expertise of DOS, DoD, and USAID [3].

\section{Embassies and Irregular Warfare}

Furthermore, in his explanation Carson as referenced in Bray 2011, stated that the TSCTP was designed with the goal of coordinating or synchronizing the interagency effort at three levels. The first level of coordination takes place at the sub-deputy level in Washington [17]. The second level consists of representatives in Washington and USAFRICOM meeting regularly with embassies in the TSCTP countries, (Ibid). The final level of coordination is at the embassy level. Carson noted that while various assessments and input from and throughout the interagency inform decisions regarding TSCTP programming, ambassadors are responsible for implementation. They are best placed to understand the immediate and long-term implications of various activities and are ultimately the primary interlocutor with the host countries [3]. Bray referencing the committee report stated that, in 2006, the Senate Foreign Relations Committee held hearings that examined Embassies as Command Posts in the Anti-Terror Campaign [18]. This indicate the role being played by embassies of major powers in the stability and peace, by implication instability of the region.

The TSCTP requires the facilitation of multilateral and multiagency partnerships across the region, with this strategic move the US ensures the involvement of its allies in its intervention, by essence 
avoiding a unilateral intervention. which steers the US away from its tendency to intervene unilaterally. This can be seen through France's continued request for intelligence support from AFRICOM and NATO, via Operation Barkhane, and the engagement of TSCTP with the G5 Sahel, ECOWAS and other partner consortiums [19].

However, consequently in 2004 referring to the Sahel Zone, the International Crisis Group went as far as to charge the DoD of creating a threat where none existed [20]. Additionally, a study from a Finnish think tank stated that in the competition for scarce resources the Department of State identified terrorism as problems in the region in order to attract funds. While, Theresa Whelan, the Deputy Assistant Secretary of Defense for African Affairs, called the program a little bit of a band aid approach [21]. Supporting this claim Prof. A.M. Okolie \& Nnamani K.E in their United States' Tran-Saharan Counter-Terrorism Partnership and Management of Boko Haram Insurgency in Nigeria, 2005-2015 submitted that, the counter-terrorism strategies adopted by the US led Trans Saharan Counterterrorism Partnership has not achieved its core goals [22]. Further to the above, I submit in agreement with Bray that in practice, it is noticeable and evident that the TSCTP has been promoting principles that encourage sectarian behavior, allowing states to crack down on ethnic minorities, Muslim groups and political opposition [3].

\section{France Strategic Counterterrorism Opera- tions in the Sahel: a Narrative of Operation Serval and Barkhane}

France wields a level of influence in sub-Saharan Africa that it cannot command anywhere else in the world. In crisis situations, it is still seen as a key source of diplomatic, military or even financial pressure on or support for the countries in the region [23]. Africa accounts for 3 per cent of France's exports and remains an important supplier of oil and metals - uranium from Niger is particularly strategic for energy security as about one-quarter of France's electricity production depends on it. So therefore, any course to undermine France business and influence will require its attention. To this end, France launched its military intervention in Mali in January 2013 with the mandate to stop an uprising of various militant groups in the north, threatening the stability and sovereignty of the country. The goal was then to free the northern part of the country from jihadist occupation, bring back peace, and restore Malian sovereignty on the whole territory. However, the defence minister of France announced that "Operation Serval" had "fulfilled its mission", but Mali is hardly a peaceful place today [24].

The fall/ousting of the former Libyan leader, Muammar Gaddafi birthed a new level and dimension of the movement of weapons in Africa in general and Sahel region in particular, which in turn affected Mali and led to a rebellion by the National Movement for the Liberation of Azawad (MNLA) with the weapons against the government of Mali. The rebellion which had it starts in January 2012, had in June same year developed into the claim for secession and independence between the MNLA and the terrorist groups Ansar Dine and the Movement for Oneness and Jihad in West Africa (MUJAO) in respect of northern Mali. By December 2012 (same year) United Nations Security Council Resolution reached a resolution (called resolution 2085106), consequently, an official request of invitation was made by the government of Mali to France, which led to the French military intervention in the northern Mali - the operation nicknamed "Operation Serval". The operation filled with highly capable forces who had subject matter expertise and intelligence training on the cultural context in Mali with organizational skills to train and interoperate military missions with other security forces in Sahel region in general and West Africa in particular. The forces were reduced in May, 2013 and the remains were mandated to support the UN Mission in Mali
(MINUSMA), the ECOWAS mission (AFISMA), the EU mission (EUTM Mali) and the government of Mali's forces in the conduct of further fight against the insurgent [25].

Following the drawdown of Operation Serval then came a new dimension of the operation by France tagged "Operation Barkhane" stationed in N'Djamena, Chad as its command post on the $1^{\text {st }}$ August, 2014 aimed at being a long-term counterinsurgency operation in the region by France. The Operation aimed at supporting the G5 Sahel armed forces in their actions in fighting and preventing terrorists and non-state armed groups and the reconstitution of its sanctuaries in the ungoverned territories in Sahel [19]. In boots on ground and missions of "Operation Barkhane", it has a base of 1,000 troops in Mali, 3,000 soldiers deployed to support the G5 Sahel member state militaries in train and equip missions and bilateral joint actions. Including, an intelligence centre in Niger, a special forces centre in Burkina Faso and operational bases to support deployment from Cote d'Ivoire, Senegal and Gabon.

Further to the above, it is not far-fetched that the drawdown of Operation Serval, was a pretext by the French government to increase its military foothold in the region, which seemingly had been an uncovered agenda of the French government towards its former colonies. This is supported by some critiques of the evolved Operation - "Operation Barkhane", as it has not stimulated states to build up their own militaries. Also owing to the argument that radicalization cannot be prevented by the use of force alone (the use of military means), which Operation Barkhane lacks. The later needs the incorporation of programmes that enhances development as a measure to countering violent extremism in the region [26].

Consequently, more than half of the half-million civilians displaced from northern Mali by the 2012-13 conflict have not returned home yet. The French intervention and operation in the region suggest that it was a tactical rather than a strategic defeat. To this end Richard Reeve, outlined Five strategic failures of the French intervention [27].

$\mathrm{He}$ stated the diagnosis of the problem in Mali as an acute incidence of jihadist terrorism rather than a chronic or cyclical domestic political crisis, as the first failure. Although, France intervention displaced AQIM and other main jihadist elements from their safe havens in northern Mali, but it hasn't been able to resolve the prior armed conflict between the Malian state and the secular Tuareg separatist groups, which took control of Kidal district.

Secondly, another shortcoming has been that the French ability to use superior conventional forces to repulse a conventional offensive and recapture territory, but so easily been unable to hold that ground against the asymmetric and unconventional tactics of a dispersed terrorist adversary.

Thirdly, France attempt to destroy highly mobile transnational armed groups with a campaign limited to one country that obviously has open borders. Thus, Opération Serval displaced the jihadist problem from Mali into neighbouring countries, especially Niger, Nigeria.

The fourth strategic own goal was Barkhane seemingly being blind to the toxic nature of its partners (The concept of 'partnership' with Sahel militaries).

The fifth and most important critique of French counter-terrorism programmes in the Sahel-Sahara should be in terms of governance outcomes. The operation Serval and Barkhane in maintaining relationship with its partners has one way or another strengthened a number of non-democratic regimes considering the perception of reliable partners in the "war on terrorism" seems to be strongly correlated to authoritarian regimes' investment in their security forces. The Algerian Pouvoir, the quasi-military Mauritanian government and especially the Déby government in Chad are thus pillars of French (and, increasingly, US) counter-terrorism strategies for the Sahel-Sahara. 


\section{Conclusion}

The study examined the efficacy of the strategies of major powers such as France and the United States in ensuring security and stability in the Sahel Zone. With special attention to US led Trans Saharan Counter-Terrorism Partnership (TSCTP) in combating terrorism and France Operation Serval and Barkhane in the fight against terrorism in the region. It's observed that Opération Serval in essence displaced and spread the jihadist problem from Mali into neighbouring countries, especially Niger, Nigeria. While, Barkhane seemingly being blind to the toxic nature of its partners. Thus, creating overdependence of the government of the affected countries on economic and military assistance of Western nations, as it diminishes the former's status and makes it vulnerable to the manipulation of the latter. The paper however posits in agreement with Bray that in practice, it is noticeable and evident that the TSCTP has been promoting principles that encourage sectarian behavior, allowing states to crack down on ethnic minorities, Muslim groups and political opposition. Adding that, religious radicalization cannot be prevented through military means alone. Additionally, this paper recommends for a paradigm shift in the affected countries foreign policy thrust wherein attentions would be shifted to strengthening the bilateral ties between the country and the emerging economies (China, Russia, Brazil and India). The paper also recommends a heal thy self-approach as panacea for addressing the menace of insurgency in the region.

The global war on terror was a misnomer and not very helpful in describing the post $9 / 11$ world of conflict. It eventually played out as more of a visceral national reaction than a strategy. If warfare is to be conducted against small bands of insurgents in a large undeveloped territory, the war must be fought differently than by the confrontation of armies lined up against each other in battle. Keeping enough troops on the ground in such a vast area creates overextended supply lines which are difficult to secure, Busch G.K. [13]. Dealing and engaging these consequences of a flawed military intervention strategy in order to build more sustainable peace and security in the Sahel will not be easy or quick. A political solution to the domestic conflict is the key element for which the responsibility lies very much with the governments of the affected region.

\section{References}

[1] Kennedy-Boudali L (2009), Published Transcript, Senate Testimony, Committee on Foreign Relations. Subcommittee on African Affairs, United States Senate.

[2] Kilcullen D, The Accidental Terrorist. Oxford: Oxford University Press, 2009, 34-35.

[3] Bray FJ (2011), The Trans-Sahara Counterterrorism Partnership: Strategy and Institutional Friction. United States Foreign Service, Strategic Research Project. U.S. Army War College, Carlisle Barracks.

[4] Crisp J (2010), Forced Displacement in Africa: Dimensions, Difficulties, and Policy Directions. Refugee Survey Quarterly, 1 29(3).

[5] Bernard A (2016), Securitizing the Desert: An Analysis of Counterterrorism Operations Impacts in New Theatres, Gaps, Shortcomings and Recommendations for Change. Birkbeck Law Review, 4(1), 2964.

[6] Conry B (1994), The Futility of U.S. Intervention in Regional Conflicts. Cato Institute Policy Analysis, 209.

[7] Choi S-W \& Powers MD (2010), Military Interventions and Transnational Terrorism: An Intense Relationship. ResearchGate. https://www.researchgate.net/publication/228214323

[8] Azikiwe A (2014), Western Intervention Fosters Instability in Africa. Global Research. https://www.globalresearch.ca/westernintervention-fosters-instability-in-africa/5383572

[9] Courtney AF (2008), The Flaws of Interventionism. The Harvard Crimson. http://www.thecrimson.com/article/2008/2/13/the-flawsof-interventionism-a-recent/

[10] Reeve R (2014), Briefing: Security in the Sahel Part II - Militarisation of the Sahel. Okford Research Group, 5. http://www.oxfordresearchgroup.org.uk/publications/briefing_pape rs_and_reports/militarisation_of_the_sahel

[11] Zyck SA \& Muggah R (2013), Conflicts Colliding in Mali and the Sahel. Stability. International Journal of Security and Development, 2(2), Art. 16

[12] Keenan JH (2016), Instability and Terrorism in Africa's Sahel: A Primer. Just Security. https://www.justsecurity.org/28972/instability-terrorism-africassahel-primer/

[13] Busch GK (2013), The Logistics of the War in the Sahel. Stability. International Journal of Security and Development, 2(2), Art. 22.

[14] Miles W (2012), Deploying Development to Counter Terrorism: Post-9/11 Transformations of US Foreign Aid to Africa. African Studies Review, 55(3), 27.

[15] Pope W (2005), Eliminating Terrorist Sanctuaries: The Role of Security Assistance. Washington, DC.

[16] Jo Choate M (2007), USMC, Trans-Sahara Counterterrorism Initiative: Balance of Power?' USAWC Strategy Research Project.

[17] Carson J (2009). Assistant Secretary of State, Bureau of African Affairs, Opening Remarks for Hearing on Counterterrorism in Africa (Sahel Region). Senate Committee on Foreign Relations, Subcommittee on Africa, Washington, D.C.

[18] Committee Report, Embassies as Command Posts in the AntiTerror Campaign, Senate Foreign Relations Committee, 109th Congress, Second Session, US Government Printing Office (Washington, DC), December 15, 2006

[19] Ministere de la Défense, République Française (2016), Operation Barkhane http://www.defense.gouv.fr/operations/sahel/dossierdepresentation-de-1-operation-barkhane/operation-barkhane

[20] Islamist Terrorism in the Sahel: Fact or Fiction? (2005). The International Crisis Group, Report Number 92. Africa. https://www.crisisgroup.org/africa/central-africa/chad/islamistterrorism-sahel-fact-or-fiction

[21] Miles D (2005), New Counterterrorism Initiative to Focus on Saharan Africa. Armed Forces Press Service. http://archive.defense.gov/news/newsarticle.aspx?id=31643

[22] Okolie AM \& Nnamani KE (2016), United State's Tran-Saharan Counter-Terrorism Partnership and Management of Boko Haram Insurgency in Nigeria, 2005-2015. ResearchGate. https://www.researchgate.net/publication/315687953_united_states $\% 27$ trans-saharan counter-

terror-

ism partnership and management of boko haram insurgency in nigeria_2005-2015

[23] Melly P \& Darracq V (2013), A New Way to Engage? French Policy in Africa from Sarkozy to Hollande. Chatham House.

[24] Pape SK (2014), Mali: The forgotten war. Aljazeera. http://www.aljazeera.com/indepth/opinion/2014/09/mali-forgottenwar-20149691511333443.html

[25] Shurkin M (2014), France's War in Mali: Lessons for an Expeditionary Army. RAND.

[26] Gnanguênon A (2014), Operation Barkhane: A Show of Force and Political Games in the Sahel-Sahara. https://issafrica.org/isstoday/operation-barkhane-a-show-of-force-and-political-games-inthe-sahel-sahara

[27] Reeve R (2015), Five strategic failures of the French intervention in Mali. The Broker. http://www.thebrokeronline.eu/Blogs/SahelWatch-a-living-analysis-of-the-conflict-in-Mali/Five-strategicfailures-of-the-French-intervention-in-Mali 